\title{
Effects of substituents on the NMR features of basic bicyclic ring systems of fluoroquinolone antibiotics and the relationships between NMR chemical shifts, molecular descriptors and drug-likeness parameters
}

MILENA JADRIJEVIĆ-MLADAR TAKAČ

Faculty of Pharmacy and Biochemistry University of Zagreb, Zagreb, Croatia

Accepted May 13, 2010
In the present study, the NMR spectroscopic features of trovafloxacin (TVA) mesylate, pefloxacin (PFX) mesylate dihydrate and ciprofloxacin (CIP) hydrochloride monohydrate were studied in DMSO- $d_{6}$ solution with the aim of investigating the effects of substituents and the type of salt on the NMR parameters of basic bicyclic fluoroquinolone and fluoronaphthyridone ring systems. For this purpose, the ${ }^{1} \mathrm{H}$ - and ${ }^{13} \mathrm{C}$ - one- and two-dimensional homo- and heteronuclear NMR methods were used. The analysis of ${ }^{1} \mathrm{H}$ - and ${ }^{13} \mathrm{C}$-NMR spectra confirmed the structures of investigated fluoroquinolone salts. Relationships between ${ }^{1} \mathrm{H}$ - and ${ }^{13} \mathrm{C}-\mathrm{NMR}$ chemical shifts of fluoronaphthyridone and fluoroquinolone ring systems, calculated molecular descriptors (MDs) and drug-likeness scores (DLSs), computed for monoprotonic cations of investigated fluoroquinolone salts $\left(\mathrm{TVAH}^{+}, \mathrm{PFXH}^{+}\right.$and $\mathrm{CIPH}^{+}$), were also explored. The topological polar surface area (TPSA), the parameter of lipophilicity $(\operatorname{miLog} P)$, the relative molecular mass $\left(M_{\mathrm{r}}\right)$ and the volume $(V)$ of computed molecular descriptors (MDs), as well as the $G$ protein-coupled receptor ligand-likeness (GPCR ligand-ls), the ion channel ligand-likeness (ICL-ls), the kinase inhibitor-likeness (KI-ls) and the nuclear receptor ligand-likeness (NRL-ls) were used in this study. The ${ }^{1} \mathrm{H}-\mathrm{NMR}$ chemical shifts of protons in $\mathrm{COOH}, \mathrm{H} 5$ and $\mathrm{NH}_{n}{ }^{+}$, as well as ${ }^{13} \mathrm{C}$-NMR chemical shifts of $\mathrm{C} 4, \mathrm{C} 5$ and $\mathrm{C} 11$ shown to be good parameters in exploration of property-property and property-drug-likeness relationships for investigated fluoroquinolone salts. Thus, collinear relationships of ${ }^{1} \mathrm{H}-\mathrm{NMR}$ chemical shifts of protons in $\mathrm{COOH}, \mathrm{H} 5$ and $\mathrm{NH}_{n}{ }^{+}$with TPSA and miLogP, as well as with GPCR ligand-ls, KI-ls and NRL-ls were revealed $(\delta$, ppm $\mathrm{H}$ in $\mathrm{COOH}$ vs. TPSA, $R=-0.9421 ; \delta$, ppm $\mathrm{H}$ in $\mathrm{COOH}$ ws. NRL-ls, $R=-0.9216 ; \delta$, ppm H5 vs.

\footnotetext{
*Correspondence; e-mail: mladar@pharma.hr, jmtmilena@gmail.com
} 
$\operatorname{miLog} P, R=0.9962 ; \delta$, ppm H5 vs. KI-ls, $R=0.9969 ; \delta$, ppm $\mathrm{NH}_{n}{ }^{+}$vs. TPSA, $R=-0.9875$ and $\delta$, ppm $\mathrm{NH}_{n}{ }^{+}$vs. NRL-ls, $R=-0.9948)$. The collinearities between, ${ }^{13} \mathrm{C}$-NMR chemical shifts of C4, C5 and C11 with KI-ls and NRL-ls, as well as with TPSA, $\operatorname{miLog} P, M_{\mathrm{r}}$ and $V$ were also revealed $(\delta$, ppm C4 vs. TPSA, $R=0.9964 ; \delta$, ppm C4 vs. miLogP, $R=0.9487 ; \delta$, ppm C4 vs. $M_{\mathrm{r}}, R=$ $0.9629 ; \delta$, ppm C4 vs. KI-ls, $R=0.9461 ; \delta$, ppm C4 vs. NRL-ls, $R=0.9996 ; \delta$, ppm C5 vs. miLogP, $R=0.9994 ; \delta$, ppm C5 vs. KI-ls, $R=0.9990 ; \delta$, ppm C5 vs. NRL-ls, $R=$ $0.9510 ; \delta$, ppm C11 vs. TPSA, $R=-0,9958 ; \delta$, ppm C11 vs. NRL-ls, $R=-0.9994$ and $\delta$, ppm C11 vs. KI-ls, $R=$ $-0.9481)$.

Keywords: fluoroquinolone antibiotics, trovafloxacin, pefloxacin, ciprofloxacin, ${ }^{1} \mathrm{H}-\mathrm{NMR}$ spectroscopy, ${ }^{13} \mathrm{C}-\mathrm{NMR}$, spectroscopy, molecular descriptors, drug-likeness scores, QSAR

Fluoroquinolones are synthetic antibacterial agents, widely prescribed for the treatment of infections in humans, with a broad antibacterial spectrum of activity against Gram-positive, Gram-negative and mycobacterial pathogens as well as anaerobes. The bacterial effects of fluoroquinolones inhibit the function of bacterial DNA gyrase and topoisomerase IV (1-3). Trovafloxacin (TVA) is a fluoronaphthyridone derivative related to fluoroquinolones, and it belongs to the class of fourth generation quinolones with a broad spectrum of antibiotic activity. It has better Gram-positive bacterial coverage and less Gram-negative coverage than the previous fluoroquinolones, and in comparison with fluoroquinolones of the third generation, it possesses additional anaerobic coverage. Chemically, TVA is 7-[(1R,5S)-6-amino-3-azabicyclo[3.1.0]hexan-3-yl]-1-(2,4-difluorophenyl)-6-fluoro-4-oxo-1,8-naphthyridine-3-carboxylic acid. It has been used to treat serious infections, including life-or-limb-threatening infections, pneumonia, complicated abdominal infections, as well as skin, gynecologic and pelvic infections $(4,5)$. In comparison with other fluoroquinolones, the pharmacokinetic data for TVA suggests significant differences in the metabolism and excretion of this agent. Phase II metabolic reactions for most fluoroquinolones were observed, and the metabolism occurs mainly by oxidative mechanisms [pefloxacin (PFX) and norfloxacin], or the drug is excreted unchanged in urine [ofloxacin and ciprofloxacin (CIP)], while fecal elimination is the primary route of TVA excretion in humans. TVA is metabolized primarily by the liver (via glucuronidation $13.2 \%, N$-acetylation $10.4 \%$, and $N$-sulfoconjugation $4.1 \%$ ), and the role of cytochrome $\mathrm{P} 450$ oxidative metabolism seems to be an insignificant route in its metabolism (6).

Marketing authorisations of TVA mesylate tablets, intended for oral use, and its prodrug alatrofloxacin mesylate, i.e., L-alanyl-L-alanyl prodrug for infusion, were withdrawn in 2001, following restriction in 1999 due to hepatotoxicity risk (7). Thus, TVA shared similar fate at the market as some other fluoroquinolones, which were removed 
M. Jadrijević-Mladar Takač: Effects of substituents on the NMR features of basic bicyclic ring systems of fluoroquinolone antibiotics and the relationships between NMR chemical shifts, molecular descriptors and drug-likeness parameters, Acta Pharm. 60 (2010) $237-254$.

or their clinical use was restricted in many countries, e.g., enoxacin (fluoronaphthyridone derivative), fleroxacin, temafloxacin, grepafloxacin, and newer fluoroquinolones, sparfloxacin and gatifloxacin. For instance, temafloxacin was withdrawn in 1992 because of serious adverse drug reactions, including allergic reactions and hemolytic anemia, and grepafloxacin was withdrawn in 1999 due to its side effect of lengthening the QT interval on the electrocardiogram, leading to cardiac events and sudden death. Like in the case of temafloxacin, the toxic effects of TVA were not evident until after the drug was in widespread clinical use.

Recently, the possible mechanisms of TVA hepatotoxicity were discussed in several papers (8-10). Thus Liguori et al. (2005) used a method of microarray analysis on isolated human hepatocytes by which they clearly distinguished between TVA and other marketed quinolone agents, and identified unique gene changes induced by TVA that are involved in mitochondrial damage, RNA processing, transcription, and inflammation, which may suggest a possible mechanism for the hepatotoxicity induced by this agent $(8)$. Sun et al. $(9,10)$ suggested a model of a cyclopropylamine-containing system that implies oxidation of cyclopropylamine moiety to reactive ring-opened intermediates with a carbon-centered radical, which can be subsequently converted to $\alpha, \beta$-unsaturated aldehyde. They suggested that TVA-induced hepatotoxicity may be mediated by reactive intermediates that may form covalent adducts to hepatic proteins, resulting in hepatocyte necrosis and damage to liver tissue. Another possible mechanism of TVA hepatotoxicity includes the $\mathrm{N}$-acetyl metabolite formation at the primary amino group, since the site of $N$-acylation occurs in liver and the $N 7^{\prime}$-acetyl metabolite was found among major metabolites in humans together with $N 7^{\prime}$-sulfate and C11-ester glucuronide. Further metabolic reactions of $\mathrm{N}$-acetyl metabolite may result in formation of the eventual toxin. The full mechanism of TVA hepatotoxicity still remains unresolved $(9,10)$.

There is a large amount of literature about fluoroquinolones addressing the effect of modifying each carbon in the molecules of the central bicyclic nucleus (11-13). Nowadays, fluoroquinolones with their unique structure and biological activity, as well as the TVA molecule, still attract the attention of researchers with regard to the synthesis of new derivatives, new pharmacological activities including antitumor activity, QSAR, salt formation and complexes with metal cations, clinical usefulness, and the possible mechanisms of toxicity and structure-side-effect-relationships (14-18). The structures of fluoroquinolones are directly reflected in their pharmacological effect and side-effect profiles. In addition to the $\beta$-keto-carboxylic group of the quinolone bicyclic ring system at positions 3 and 4, fluoroquinolones possess a fluorine atom at position C6. While the $\beta$-keto-carboxylic group is responsible for the basic pharmacological activity and acts as a binding site, the fluorine atom is responsible for cell penetration and gyrase affinity. Other substituents, positioned at N1 and C7, are responsible for the overall potency and antibacterial spectrum, and position $X 8(X=N)$ for the antianaerobic spectrum. However, changes in the basic fluoroquinolone pharmacophore moiety as well as changes in substituents lead to unexpected adverse reactions, such as the CNS reactions, drug-drug interactions, phototoxicity, hepatotoxicity and cardiotoxicity such as QTc interval prolongation of electrocardiogram, which have been reported in clinical evaluations or the post-marketing surveillance of several new quinolones (7). Similarly, as found for the pharmacological effect, the relationships of the structure and adverse effects were observed and specific substituent side effects were revealed $(11,13)$. 
M. Jadrijević-Mladar Takač: Effects of substituents on the NMR features of basic bicyclic ring systems of fluoroquinolone antibiotics and the relationships between NMR chemical shifts, molecular descriptors and drug-likeness parameters, Acta Pharm. 60 (2010) $237-254$.

The aim of this study was to investigate the substituent effects, as well as salt type, on the basic bicyclic ring systems of TVA mesylate in comparison with PFX mesylate, and CIP hydrochloride by ${ }^{1} \mathrm{H}$ - and ${ }^{13} \mathrm{C}-\mathrm{NMR}$ spectroscopies and to explore the possibility of NMR chemical shift use in fluoroquinolone antibiotics QSAR studies.

\section{EXPERIMENTAL}

\section{Materials}

Fluoroquinolones used in this study were donated as reference samples of analytical grade purity from manufacturers, pharmaceutical companies, i.e., CIP hydrochloride monohydrate from Krka d.d. (Slovenia), PFX methanesulfonate (mesylate) dihydrate from Lek d.d. (Slovenia) and TVA mesylate from Pfizer Inc. (USA). For NMR spectroscopic measurements, deuterated dimethylsulfoxide- $d_{6}$ with tetramethysilane (TMS) $(0.03 \%)$, (DMSO- $\left.d_{6}\right)$, with deuteration degree min. $99.8 \%$ and analytical grade for spectroscopy (Merck, Germany), were used without further purification.

\section{NMR studies}

The ${ }^{1} \mathrm{H}$ - and ${ }^{13} \mathrm{C}$ - one- and two-dimensional NMR spectra were recorded using a Varian Gemini 300 spectrometer (Varian, USA) operating at $300 \mathrm{MHz}$ and $75.5 \mathrm{MHz}$ for the ${ }^{1} \mathrm{H}$ - and ${ }^{13} \mathrm{C}$ - nucleus, respectively. All samples were measured from DMSO- $d_{6}$ solutions at $20^{\circ} \mathrm{C}$ in 5-mm NMR tubes. Chemical shifts $(\delta)$, in ppm, are referred to TMS as internal standard, and coupling constants $(J)$ are given in Hz. Digital resolution in ${ }^{1} \mathrm{H}-\mathrm{NMR}$ spectra was $0.20 \mathrm{~Hz}$, while it was $0.63 \mathrm{~Hz}$ per point in ${ }^{13} \mathrm{C}$-NMR spectra. The following spectra were recorded: standard ${ }^{1} \mathrm{H}$ - and ${ }^{13} \mathrm{C}$ - broadband proton decoupled, ${ }^{13} \mathrm{C}$ - gated proton decoupled, APT, COSY-45, NOESY and HECTOR. In all experiments, the proton decoupled spectrum was performed by Waltz-16 modulation. In two-dimensional experiments, the standard sequence pulse was used. The COSY-45 spectra and delayed COSY-45 spectra were measured in the magnitude mode and NOESY spectra in the "phase sensitive mode«. The COSY-45, the delayed COSY-45 and NOESY spectra were measured in the magnitude mode using 1024 points in F2 dimension and 256 increments in F1 dimension, subsequently zero-filled to 1024 points. Each increment was obtained with 16 scans, $3000 \mathrm{~Hz}$ spectral width and relaxation time delay of $1 \mathrm{~s}$. The corresponding digital resolution was $5.9 \mathrm{~Hz}$ /point and $11.7 \mathrm{~Hz} /$ point for F2 and F1 dimensions, respectively. The NOESY spectrum was measured with several time lapses (0.45-1.2 s). The HECTOR spectrum was recorded with 2048 points in F2 dimension and 256 increments in F1 dimension, zero-filled to 512 points. Increments were recorded with 64 scans, relaxation time of $1 \mathrm{~s}$ and spectral width of $20000 \mathrm{~Hz}$ in F2 and $4500 \mathrm{~Hz}$ in F1 dimension. The corresponding digital resolution was 19.53 and $17.6 \mathrm{~Hz} /$ point in F2 and F1 dimensions, respectively. 
M. Jadrijević-Mladar Takač: Effects of substituents on the NMR features of basic bicyclic ring systems of fluoroquinolone antibiotics and the relationships between NMR chemical shifts, molecular descriptors and drug-likeness parameters, Acta Pharm. 60 (2010) 237-254.

\section{Computation and data processing}

Lipinski's rule-of-five analysis and parameters (miLog $P, M_{\mathrm{r}}$, TPSA, $n$ atoms, $n$ ON, $n \mathrm{OHNH}, n$ rotatable bonds, volume) as well as drug-likeness scores for GPCR ligand, ion channel modulator, kinase inhibitor and nuclear receptor ligand were calculated using Molinspiration molecular processing engine, version 2007.10. (19-22). Molinspiration molecular processing data were calculated for the cationic part of each investigated fluoroquinoline salt, i.e., trovafloxacin mesylate cation $\left(\mathrm{TVAH}^{+}\right)$, pefloxacin mesylate cation $\left(\mathrm{PFXH}^{+}\right)$and ciprofloxacin hydrochloride cation $\left(\mathrm{CIPH}^{+}\right)$at the presumption that salt formation occurred on the nitrogen atom $\mathrm{N}^{\prime}$ in the piperazine ring of pefloxacin and ciprofloxacin molecule and at the amino group in TVA molecule. The simplified molecular input line entry system (SMILES) and calculated parameters (Table I) for each fluoroquinolone cation are as follows:

ciprofloxacin cation $\left(\mathrm{CIPH}^{+}\right.$or $\left.\mathrm{RR}^{\prime} \mathrm{NH}_{2}^{+}\right)$:

SMILES $[\mathrm{H}][\mathrm{N}+] 4([\mathrm{H}]) \mathrm{CCN}(\operatorname{ccc} 2 \mathrm{c}(\operatorname{cc} 1 \mathrm{~F}) \mathrm{c}(=\mathrm{O}) \mathrm{c}(\mathrm{C}(=\mathrm{O}) \mathrm{O}) \mathrm{cn} 2 \mathrm{C} 3 \mathrm{CC} 3) \mathrm{CC} 4$;

pefloxacin cation $\left(\mathrm{PFXH}^{+}\right.$or $\left.\mathrm{RR}^{\prime} \mathrm{R}^{\prime \prime} \mathrm{NH}^{+}\right)$:

SMILES $[\mathrm{H}][\mathrm{N}+] 3(\mathrm{C}) \mathrm{CCN}(\mathrm{c} 1 \mathrm{cc} 2 \mathrm{c}(\mathrm{cc} 1 \mathrm{~F}) \mathrm{c}(=\mathrm{O}) \mathrm{c}(\mathrm{C}(=\mathrm{O}) \mathrm{O}) \mathrm{cn} 2 \mathrm{CC}) \mathrm{CC} 3$;

trovafloxacin cation $\left(\mathrm{TVAH}^{+}\right.$or $\left.\mathrm{RNH}_{3}{ }^{+}\right)$:

SMILES $[\mathrm{H}][\mathrm{N}+]([\mathrm{H}])([\mathrm{H}]) \mathrm{C} 5 \mathrm{C} 4 \mathrm{CN}(\mathrm{c} 1 \mathrm{nc} 2 \mathrm{c}(\mathrm{cc} 1 \mathrm{~F}) \mathrm{c}(=\mathrm{O}) \mathrm{c}(\mathrm{C}(=\mathrm{O}) \mathrm{O}) \mathrm{cn} 2 \mathrm{c} 3 \mathrm{ccc}(\mathrm{F}) \mathrm{cc} 3 \mathrm{~F}) \mathrm{CC} 45$.

All analyses were performed and data were graphed using the OriginPro 7.5 software (Origin Laboratories, USA).

Table I. Calculated molecular descriptors (MDs) and drug-likeness scores (DLSs) for investigated fluoroquinolone cations

\begin{tabular}{|c|c|c|c|c|}
\hline & $\begin{array}{l}\text { Calculated } \\
\text { parameter }\end{array}$ & $\begin{array}{l}\text { Ciprofloxacin } \\
\text { cation }\left(\mathrm{CIPH}^{+}\right. \\
\left.\text {or } \mathrm{RR}^{\prime} \mathrm{NH}_{2}^{+}\right)\end{array}$ & $\begin{array}{c}\text { Pefloxacin } \\
\text { cation }\left(\mathrm{PFXH}^{+}\right. \\
\left.\text {or } \mathrm{RR}^{\prime} \mathrm{R}^{\prime \prime} \mathrm{NH}^{+}\right)\end{array}$ & $\begin{array}{l}\text { Trovafloxacin } \\
\text { cation }\left(\mathrm{TVAH}^{+}\right. \\
\left.\text {or } \mathrm{RNH}_{3}{ }^{+}\right)\end{array}$ \\
\hline \multirow{9}{*}{$\begin{array}{l}\text { Molecular } \\
\text { descriptors } \\
\text { (MDs) }\end{array}$} & $\operatorname{miLog} P$ & -3.365 & -3.255 & -1.936 \\
\hline & TPSA & 79.147 & 66.978 & 103.076 \\
\hline & $n$ atoms (without $\mathrm{H}$ ) & 24 & 24 & 30 \\
\hline & Relative molecular mass $\left(M_{\mathrm{r}}\right)$ & 332.355 & 334.371 & 417.367 \\
\hline & $n \mathrm{ON}$ & 6 & 6 & 7 \\
\hline & $n$ OHNH & 3 & 2 & 4 \\
\hline & $n$ violations & 0 & 0 & 0 \\
\hline & $n$ rotatable bonds & 3 & 3 & 3 \\
\hline & Volume $(V)$ & 286.436 & 299.289 & 328.708 \\
\hline \multirow{4}{*}{$\begin{array}{l}\text { Drug-likeness } \\
\text { scores (DLSs) }\end{array}$} & GPCR ligand & 0.11 & -0.07 & -0.02 \\
\hline & Ion channel modulator & 0.45 & 0.21 & -0.23 \\
\hline & Kinase inhibitor & -0.30 & -0.27 & 0.05 \\
\hline & Nuclear receptor ligand & -0.73 & -0.81 & -0.53 \\
\hline
\end{tabular}


M. Jadrijević-Mladar Takač: Effects of substituents on the NMR features of basic bicyclic ring systems of fluoroquinolone antibiotics and the relationships between NMR chemical shifts, molecular descriptors and drug-likeness parameters, Acta Pharm. 60 (2010) $237-254$.

\section{RESULTS AND DISCUSSION}

In this study, TVA mesylate, PFX mesylate and CIP hydrochloride belonging to the fourth, third and second generation of quinolone antibiotics, respectively, were investigated (Fig. 1).

The primary aim of this study was to explore in more detail the NMR spectroscopic features of these antibiotic structures, as well as the impact of different substituents on ${ }^{1} \mathrm{H}$ - and ${ }^{13} \mathrm{C}-\mathrm{NMR}$ chemical shifts of basic bicyclic ring systems as possible parameters in fluoroquinolone QSAR studies. For this purpose, the ${ }^{1} \mathrm{H}$ - and ${ }^{13} \mathrm{C}-\mathrm{NMR}$ spectra of TVA mesylate, PFX mesylate dihydrate and CIP hydrochloride monohydrate (Table I) were recorded in DMSO- $d_{6}$ solution.

Structures of the investigated fluoroquinolone salts were investigated by means of NMR spectroscopy, using ${ }^{1} \mathrm{H}$ - and ${ }^{13} \mathrm{C}$ - one- and two-dimensional homo- and heteronuclear NMR methods. Analyses of spectra were performed on the basis of NMR parameters, i.e. chemical shifts $(\delta / \mathrm{ppm})$ and coupling constants $\mathrm{H}-\mathrm{H}, \mathrm{F}-\mathrm{H}, \mathrm{C}-\mathrm{H}$ and $\mathrm{C}-\mathrm{F}(\mathrm{J} / \mathrm{Hz})$, as well as using the NMR substituent effects, intensities and multiplicities of signals (splitting patterns) in their one-dimensional ${ }^{1} \mathrm{H}$ - and ${ }^{13} \mathrm{C}-\mathrm{NMR}$ spectra and contours in $2 \mathrm{D}$ spectra.

The ${ }^{1} \mathrm{H}$ - and ${ }^{13} \mathrm{C}$-NMR spectral data for each fluoroquinolone salt are displayed in Tables II and III, respectively. The NOESY spectrum of TVA mesylate is shown in Fig. 2, and the ${ }^{13} \mathrm{C}$-NMR spectrum in Fig. 3. Obtained results are in good agreement with previously published data for these fluoroquinolones in the zwitter-ion or free base form (17, 24, 25).

In contrast to the PFX and CIP basic bicyclic ring system, i.e., fluoroquinolone moiety, trovafloxacin is a fluoronaphthyridone derivative and it differs in the nitrogen atom at position 8, instead of a carbon atom in bicyclic ring system of the other two fluoroquinolones (Fig. 1). This change in the basic ring system contributes to the overall elec-<smiles>[R]c1nc2c(cc1F)c(=O)c(C(=O)O)cn2[Y]</smiles>

\begin{tabular}{cccccc}
\multicolumn{3}{c}{ TVA mesylate } & PFX mesylate dihydrate & \multicolumn{2}{c}{ CIP hydochloride monohydrate } \\
\hline $\mathrm{R}^{1}$ & $\mathrm{R}^{2}$ & $\mathrm{R}^{2}$ & $\mathrm{R}^{2}$ \\
\hline & & &
\end{tabular}

Fig. 1. Structures of investigated TVA mesylate, PFX mesylate and CIP hydrochloride. 
M. Jadrijević-Mladar Takač: Effects of substituents on the NMR features of basic bicyclic ring systems of fluoroquinolone antibiotics and the relationships between NMR chemical shifts, molecular descriptors and drug-likeness parameters, Acta Pharm. 60 (2010) $237-254$.

tron distribution in trovafloxacin molecule, and not only to substituents at positions 1 and 7. The 2,4-difluoro-1-phenyl substituent at position N1 and 6-amino-3-azabicyclo[3.1.0]hexan-3-yl substituent at position C7 in TVA molecule make additional differences compared to substituents at these positions in PFX (ethyl and 4'-methyl-1'-piperazinyl) and in CIP (cyclopropyl and piperazinyl) molecules. Furthermore, TVA possesses a primary amino group, which is not usually present in other fluoroquinolones either in clinical use or among the withdrawn drugs of this group.

Structural differences in TVA compared to PFX and CIP molecule influence in a specific way its physicochemical properties, pharmacological activity, pharmacokinetic and side-effect profile. Therefore, it is expected that these structural changes also affect the NMR spectroscopic features of basic bicyclic ring systems of investigated fluoroquinolone salts.

\section{${ }^{1}$ H-NMR spectroscopy}

The ${ }^{1} \mathrm{H}-\mathrm{NMR}$ spectra of investigated fluoroquinolones showed characteristic signals for aromatic and non-aromatic protons in their molecules. Carboxylic protons $(\mathrm{COOH})$ in the spectra of TVA mesylate, PFX mesylate and CIP hydrochloride were observed downfield in the corresponding spectra as singlets $(1 \mathrm{H})$ at $\delta 15.06,15.28$ and $15.15 \mathrm{ppm}$, respectively. The decrease of chemical shifts was observed in the following order: PFX mesylate > CIP hydrochloride > TVA mesylate. It is interesting to note that in the spectrum of CIP (free base), also investigated in the broader frame of this study, the carboxylic proton was not observed up to $\delta 20 \mathrm{ppm}$, either in ${ }^{1} \mathrm{H}-\mathrm{NMR}$ spectra of concentrated or diluted DMSO- $d_{6}$ solutions of CIP. These findings indicate that CIP in the free base form exists in the form of zwitterion in DMSO- $d_{6}$ solution, independently of CIP concentration.

For the aromatic part of ${ }^{1} \mathrm{H}-\mathrm{NMR}$ spectra, the characteristic splitting pattern due to the presence of fluorine atom at C6, and additionally in TVA mesylate, at C2" and C4" in 2,4-difluorophenyl substituent, allowed a simple assignation of protons $\mathrm{H} 5$ and $\mathrm{H} 8$ of the basic fluoroquinolone ring system and protons H3", H5" and H6" in TVA mesylate. The $\mathrm{H} 5$ protons in ${ }^{1} \mathrm{H}-\mathrm{NMR}$ spectra of TVA mesylate, PFX mesylate and CIP hydrochloride were at $\delta 8.07,7.97$ and $7.95 \mathrm{ppm}$, respectively, and appear as doublets split by the fluorine atom through three bonds and with the corresponding coupling constants ${ }^{3} J_{\mathrm{H}-\mathrm{F}}$ $=12.3,{ }^{3} J_{\mathrm{H}-\mathrm{F}}=13.1$ and ${ }^{3} J_{\mathrm{H}-\mathrm{F}}=13.1 \mathrm{~Hz}$. The signal of protons $\mathrm{H} 8$ in PFX mesylate and CIP hydrochloride were at $\delta 7.29$ and $7.61 \mathrm{ppm}$, split through four bonds by the fluorine atom into doublets with coupling constants ${ }^{4} J_{\mathrm{H}-\mathrm{F}}=7.1$ and ${ }^{4} J_{\mathrm{H}-\mathrm{F}}=7.3 \mathrm{~Hz}$, respectively, while this signal was missing in the TVA mesylate ${ }^{1} \mathrm{H}-\mathrm{NMR}$ spectrum due to the fluoronaphthyridone bicyclic ring system, where $\mathrm{X}$ at position 8 is represented by $\mathrm{N}$ atom.

The $\mathrm{H} 2$ protons in ${ }^{1} \mathrm{H}-\mathrm{NMR}$ spectra of TVA mesylate, PFX mesylate and CIP hydrochloride were observed as singlets $(1 \mathrm{H})$ at $8.83,8.98$ and $8.69 \mathrm{ppm}$, respectively. The H2' and $\mathrm{H}^{\prime}{ }^{\prime}$ protons in ${ }^{1} \mathrm{H}-\mathrm{NMR}$ spectrum of TVA mesylate are observed as a broad multiplet signal $(4 \mathrm{H})$ at $\delta 3.67$, while $\mathrm{H}^{\prime}$ and $\mathrm{H}^{\prime}$ protons are displayed as a singlet $(2 \mathrm{H})$ at 2.08 ppm.

The protons of protonated primary, secondary and tertiary amino moieties in the corresponding fluoroquinolone salts, i.e., $\mathrm{RNH}_{3}{ }^{+}$in $\mathrm{TVAH}^{+}, \mathrm{RR}^{\prime} \mathrm{NH}_{2}{ }^{+}$in $\mathrm{CIPH}^{+}$, and 
M. Jadrijević-Mladar Takač: Effects of substituents on the NMR features of basic bicyclic ring systems of fluoroquinolone antibiotics and the relationships between NMR chemical shifts, molecular descriptors and drug-likeness parameters, Acta Pharm. 60 (2010) $237-254$.

$\mathrm{RR}^{\prime} \mathrm{R}^{\prime \prime} \mathrm{NH}^{+}$in $\mathrm{PFXH}^{+}$, were observed as broad singlet (bs) signals in their ${ }^{1} \mathrm{H}-\mathrm{NMR}$ spectra and are as follows: $\delta 8.18 \mathrm{ppm}(3 \mathrm{H})$ for $\mathrm{RNH}_{3}{ }^{+}$in TVA mesylate ${ }^{1} \mathrm{H}-\mathrm{NMR}$ spectrum, $\delta$ $9.55 \mathrm{ppm}(2 \mathrm{H})$ in CIP hydrochloride ${ }^{1} \mathrm{H}-\mathrm{NMR}$ spectrum and $\delta 9.87 \mathrm{ppm}(1 \mathrm{H})$ in PFX mesylate ${ }^{1} \mathrm{H}-\mathrm{NMR}$ spectrum.

All non-aromatic protons were observed upfield in the corresponding ${ }^{1} \mathrm{H}-\mathrm{NMR}$ spectra of related fluoroquinolone, and their chemical shifts, splitting patterns and coupling constants $\left({ }^{3} J_{\mathrm{H}-\mathrm{H}}\right)$ are shown in Table II.

\section{${ }^{13}$ C-NMR spectroscopy}

The ${ }^{13} \mathrm{C}-\mathrm{NMR}$ proton decoupled spectra of investigated fluoroquinolone salts recorded in DMSO- $d_{6}$ solutions showed the characteristic splitting pattern due to the presence of fluorine atom at C6, and additionally two fluorine atoms, C2" and C4", in the difluorophenyl substituent at N1 in TVA mesylate. The splitting of carbon signals with

Table II. ${ }^{1} \mathrm{H}$-NMR spectral data, chemical shifts, multiplicites, number of protons and coupling constants of TVA mesylate, PFX mesylate and CIP hydrochloride, recorded in DMSO- $d_{6}$ solution

\begin{tabular}{|c|c|c|c|}
\hline \multirow[t]{2}{*}{ H-atom } & \multicolumn{3}{|c|}{$\begin{array}{l}{ }^{1} \mathrm{H}-\mathrm{NMR} \text { chemical shifts }(\delta, \text { ppm, multiplicity and coupling constants } \\
\qquad\left({ }^{\mathrm{n}} J_{\mathrm{H}-\mathrm{F}} \text { and }{ }^{\mathrm{n}} J_{\mathrm{H}-\mathrm{H}} \text { in } \mathrm{Hz}\right)\end{array}$} \\
\hline & Trovafloxacin mesylate & Pefloxacin mesylate & Ciprofloxacin hydochloride \\
\hline$\overline{\mathrm{COOH}}$ & $15.06, \mathrm{~s}, 1 \mathrm{H}$ & $15.28, \mathrm{~s}, 1 \mathrm{H}$ & $15.14, \mathrm{bs}, 1 \mathrm{H}$ \\
\hline 2 & $8.83, \mathrm{~s}, 1 \mathrm{H}$ & $8.98, \mathrm{~s}, 1 \mathrm{H}$ & $8.69, \mathrm{~s}, 1 \mathrm{H}$ \\
\hline 5 & $8.07, \mathrm{~d}, 1 \mathrm{H},{ }^{3} J_{\mathrm{H}-\mathrm{F}}=12.3$ & $7.97, \mathrm{~d}, 1 \mathrm{H},{ }^{3} J_{\mathrm{H}-\mathrm{F}}=13.1$ & $7.95, \mathrm{~d}, 1 \mathrm{H},{ }^{3} J_{\mathrm{H}-\mathrm{F}}=13.1$ \\
\hline 8 & - & $7.29, \mathrm{~d}, 1 \mathrm{H},{ }^{4} J_{\mathrm{H}-\mathrm{F}}=7.1$ & $7.61, \mathrm{~d}, 1 \mathrm{H},{ }^{4} J_{\mathrm{H}-\mathrm{F}}=7.3$ \\
\hline $1^{\prime}$ & $2.08, \mathrm{~s}, 1 \mathrm{H}$ & - & - \\
\hline $2^{\prime}$ & $3.67, \mathrm{~m}, 2 \mathrm{H}$ & $3.32, \mathrm{~s}, 2 \mathrm{H}$ & $\mathrm{H} 2^{\prime}, \mathrm{H}^{\prime} 3.33, \mathrm{~s}, 4 \mathrm{H}$ \\
\hline $3^{\prime}$ & - & $3.90, \mathrm{~s}, 2 \mathrm{H}$ & $\mathrm{H} 3^{\prime}, \mathrm{H}^{\prime}, 3.59, \mathrm{~s}, 4 \mathrm{H}$ \\
\hline $4^{\prime}$ & $3.67, \mathrm{~m}, 2 \mathrm{H}$ & - & \\
\hline $5^{\prime}$ & $2.08, \mathrm{~s}, 1 \mathrm{H}$ & $3.90, \mathrm{~s}, 2 \mathrm{H}$ & $\mathrm{H} 4^{\prime}(\mathrm{N})$ - displayed \\
\hline $6^{\prime}$ & $3.37, \mathrm{~s}, 1 \mathrm{H}$ & $3.32, \mathrm{~s}, 2 \mathrm{H}$ & under $\mathrm{NH}_{n}{ }^{+}$ \\
\hline $\mathrm{NH}_{n}^{+}$ & $8.18, \mathrm{bs}, 3 \mathrm{H}$ & $9.87, \mathrm{bs}, 1 \mathrm{H}$ & $9.55, \mathrm{bs}, 2 \mathrm{H}$ \\
\hline $\mathrm{CH}_{3}-\mathrm{N}^{\prime}$ & - & $2.36, \mathrm{~s}, 3 \mathrm{H}$ & - \\
\hline $1^{\prime \prime}$ & - & $4.63, \mathrm{q}, 2 \mathrm{H},{ }^{3} \mathrm{~J}_{\mathrm{H}-\mathrm{H}}=6.8$ & $3.88, \mathrm{bs}, 1 \mathrm{H}$ \\
\hline $2^{\prime \prime}$ & - & $1.43, \mathrm{t}, 3 \mathrm{H},{ }^{3} J_{\mathrm{H}-\mathrm{H}}=6.9$ & $1.34, \mathrm{~d}, 2 \mathrm{H},{ }^{3} J_{\mathrm{H}-\mathrm{H}}=6.4$ \\
\hline $3^{\prime \prime}$ & $7.62, \mathrm{td}, 1 \mathrm{H},{ }^{3} J_{\mathrm{H}-\mathrm{F}}=8.6$ & - & $1.21, \mathrm{bs}, 2 \mathrm{H}$ \\
\hline $4^{\prime \prime}$ & - & - & - \\
\hline $5^{\prime \prime}$ & $7.37, \mathrm{td}, 1 \mathrm{H},{ }^{3} J_{\mathrm{H}-\mathrm{F}}=8.6$ & - & - \\
\hline $6^{\prime \prime}$ & $7.85-7.78, \mathrm{~m}, 1 \mathrm{H}$ & - & - \\
\hline $\mathrm{CH}_{3}{ }^{\mathrm{a}}$ & $2.45, \mathrm{~s}, 3 \mathrm{H}$ & $2.92, \mathrm{~s}, 3 \mathrm{H}$ & - \\
\hline
\end{tabular}

${ }^{a} \mathrm{CH}_{3}$ in mesylate moiety, $\mathrm{s}$ - singlet, bs - broad singlet, $\mathrm{d}$ - doublet, $\mathrm{t}$ - triplet, $\mathrm{td}$ - triplet of doublets, $\mathrm{q}$ - quartet, $\mathrm{m}$ - multiplet 
Fig. 2. The ${ }^{1} \mathrm{H}$ NOESY spectrum of TVA mesylate.

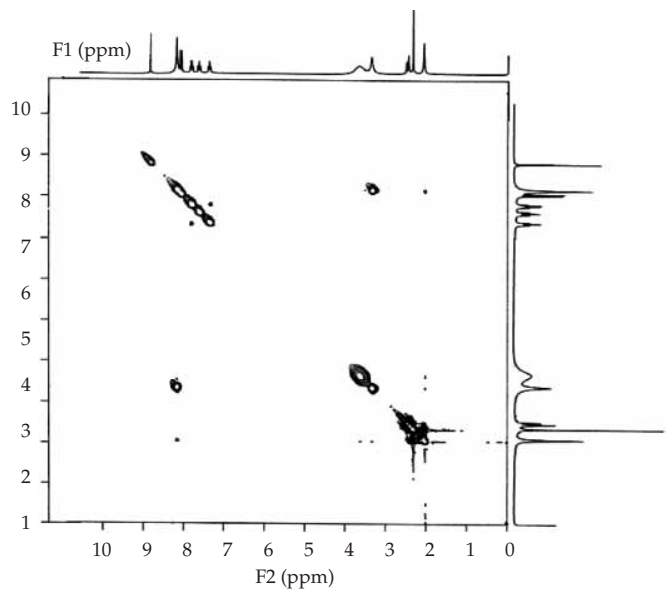

fluorine atoms was observed through one, two, three and four bonds in these molecules. The splitting of carbon signals through one bond was observed for C6 in all investigated fluoroquinolones, and additionally for C2" and C4" atoms in TVA mesylate (Fig. 3). Chemical shifts, multiplicities of signals and coupling constants $\left({ }^{n} J_{C-F}\right.$ and ${ }^{n} J_{C-H}$ in $\left.\mathrm{Hz}\right)$ for investigated salts are given in Table III. In correlation studies with molecular descriptors and drug-likeness scores, the ${ }^{13} \mathrm{C}-\mathrm{NMR}$ chemical shifts of selected carbon atoms from the basic bicyclic ring system, i.e., C4, C5 and C11, were used. An average ${ }^{13} \mathrm{C}-\mathrm{NMR}$ chemical shift $(\delta, \mathrm{ppm})$ of the basic fluoroquinolone ring system in each fluoroquinolone salt was calculated by summing up all $\mathrm{C}$ signal lines observed in their spectra, belonging to $\mathrm{C} 2$ to $\mathrm{C} 10$ including the signal for carboxylic $\mathrm{C} 11$, and by dividing the resulting sum by the number of signal lines [ $\Sigma$ signal lines $/ n$ signal lines]. The average of ${ }^{13} \mathrm{C}-\mathrm{NMR}$ chem-

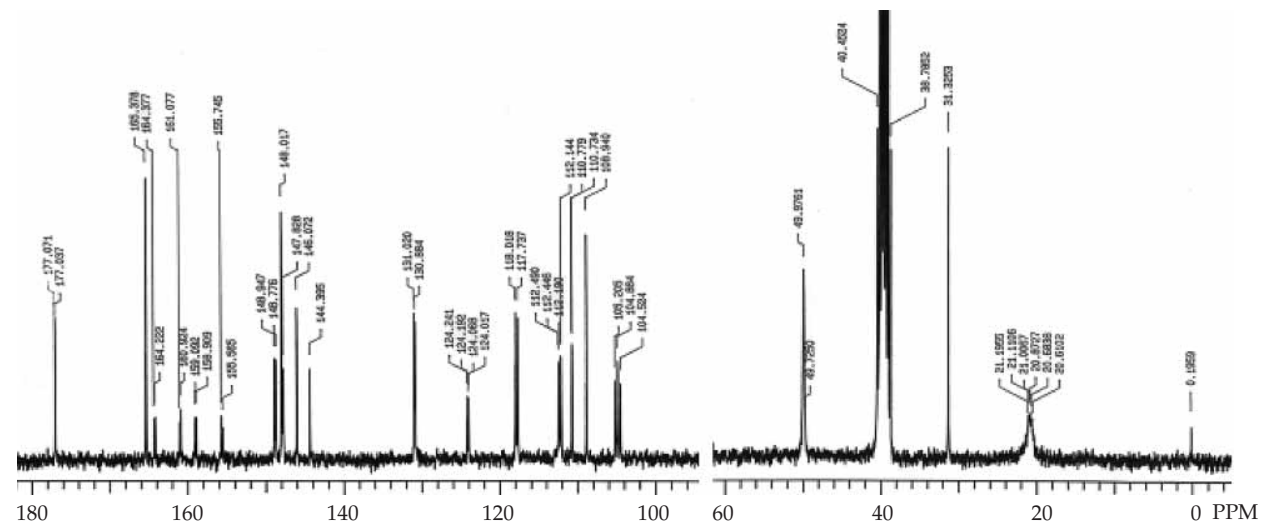

Fig. 3. The ${ }^{13} \mathrm{C}-\mathrm{NMR}$ spectrum of TVA mesylate. 
M. Jadrijević-Mladar Takač: Effects of substituents on the NMR features of basic bicyclic ring systems of fluoroquinolone antibiotics and the relationships between NMR chemical shifts, molecular descriptors and drug-likeness parameters, Acta Pharm. 60 (2010) $237-254$.

Table III. ${ }^{13} \mathrm{C}-\mathrm{NMR}$ spectral data, chemical shifts, multiplicities of signals and coupling constants of TVA mesylate, PFX mesylate and CIP hydrochloride, recorded in DMSO- $d_{6}$ solution

\begin{tabular}{|c|c|c|c|}
\hline \multirow{2}{*}{ C-atom } & \multicolumn{3}{|c|}{$\begin{array}{l}{ }^{13} \mathrm{C}-\mathrm{NMR} \text { chemical shifts }(\delta, \mathrm{ppm}), \text { multiplicity and coupling constants } \\
\qquad\left({ }^{\mathrm{n}} J_{\mathrm{C}-\mathrm{H}} \text { and }{ }^{\mathrm{n}} \mathrm{J}_{\mathrm{C}-\mathrm{F}} \text { in } \mathrm{Hz}\right)\end{array}$} \\
\hline & $\begin{array}{l}\text { Trovafloxacin } \\
\text { mesylate }\end{array}$ & $\begin{array}{l}\text { Pefloxacin } \\
\text { mesylate }\end{array}$ & $\begin{array}{l}\text { Ciprofloxacin } \\
\text { hydochloride }\end{array}$ \\
\hline $\mathrm{C} 11$ & $165.38, \mathrm{~s}$ & $166.13, \mathrm{~s}$ & $165.94, \mathrm{~s}$ \\
\hline 2 & $148.02, \mathrm{~s}$ & $148.86, \mathrm{~s}$ & $148.28, \mathrm{~s}$ \\
\hline 3 & $108.94, \mathrm{~s}$ & $107.28, \mathrm{~s}$ & $106.95, \mathrm{~s}$ \\
\hline 4 & $177.05, \mathrm{~d},{ }^{4} J_{\mathrm{C}-\mathrm{F}}=2.5$ & $176.24, \mathrm{~s}$ & $176.45, \mathrm{~d},{ }^{4} J_{\mathrm{C}-\mathrm{F}}=3.4$ \\
\hline 5 & $117.88, \mathrm{~d},{ }^{2} \mathrm{~J}_{\mathrm{C}-\mathrm{F}}=21.2$ & $111.52, \mathrm{~d} \mathrm{t},{ }^{2} J_{\mathrm{C}-\mathrm{F}}=22.7$ & $111.27, \mathrm{~d},{ }^{2} J_{\mathrm{C}-\mathrm{F}}=22.8$ \\
\hline 6 & $162.65, \mathrm{~d},{ }^{1} J_{\mathrm{C}-\mathrm{F}}=249.0$ & $152.81, \mathrm{~d},{ }^{1} J_{\mathrm{C}-\mathrm{F}}=249.2$ & $152.97, \mathrm{~d},{ }^{1} J_{\mathrm{C}-\mathrm{F}}=249.3$ \\
\hline 7 & $148.86, \mathrm{~d},{ }^{2} J_{\mathrm{C}-\mathrm{F}}=13.0$ & $144.02, \mathrm{~d},{ }^{2} J_{\mathrm{C}-\mathrm{F}}=10.6$ & $144.24, \mathrm{~d},{ }^{2} J_{\mathrm{C}-\mathrm{F}}=10.1$ \\
\hline 8 & - & $106.80, \mathrm{t},{ }^{3} J_{\mathrm{C}-\mathrm{F}}=36.2$ & $106.97,{ }^{3} J_{\mathrm{C}-\mathrm{F}}=3.8$ \\
\hline 9 & $130.95, \mathrm{~d},{ }^{3} J_{\mathrm{C}-\mathrm{F}}=10.2$ & $120.12, \mathrm{~d},{ }^{3} J_{\mathrm{C}-\mathrm{F}}=7.4$ & $119.42, d,{ }^{3} J_{C-F}=7.6$ \\
\hline 10 & $146.07, \mathrm{~s}$ & $137.19, \mathrm{~s}$ & $139.20, \mathrm{~s}$ \\
\hline $1^{\prime}$ & $20.68, \mathrm{~m}$ & - & - \\
\hline $2^{\prime}$ & $49.97, \mathrm{~s}$ & \multirow{5}{*}{$\begin{array}{l}\mathrm{C} 2^{\prime}, \mathrm{C}^{\prime} 46.74, \mathrm{td}, 2 \mathrm{C}, \\
{ }^{1} J_{\mathrm{C}-\mathrm{H}}=140.9,{ }^{4} J_{\mathrm{C}-\mathrm{F}}=4.7 \\
\mathrm{C}^{\prime}, \mathrm{C} 5^{\prime} 42.38, \mathrm{~s}, 2 \mathrm{C}\end{array}$} & \multirow{5}{*}{$\begin{array}{l}\mathrm{C} 2^{\prime}, \mathrm{C}^{\prime} 46.48, \mathrm{td}, 2 \mathrm{C}, \\
{ }^{1} J_{\mathrm{C}-\mathrm{H}}=141.1,{ }^{4} J_{\mathrm{C}-\mathrm{F}}=4.8 \\
\mathrm{C}^{\prime}, \mathrm{C} 5^{\prime} 42.59, \mathrm{t}, 2 \mathrm{C}, \\
{ }^{1} J_{\mathrm{C}-\mathrm{H}}=139.9\end{array}$} \\
\hline $3^{\prime}$ & - & & \\
\hline $4^{\prime}$ & $49.97, \mathrm{~s}$ & & \\
\hline $5^{\prime}$ & $21.11, \mathrm{~m}$ & & \\
\hline $6^{\prime}$ & $49.73, \mathrm{~s}$ & & \\
\hline $\mathrm{CH}_{3}-\mathrm{N}^{\prime}-$ & - & $49.24, \mathrm{~s}$ & - \\
\hline $1^{\prime \prime}$ & $\begin{array}{l}124.20, \mathrm{dd} \\
{ }^{3} J_{\mathrm{C}-\mathrm{F}}=3.7 \text { and } 3.9\end{array}$ & $52.27, \mathrm{~s}$ & $36.10, \mathrm{~d},{ }^{1} J_{\mathrm{C}-\mathrm{H}}=187.8$ \\
\hline $2^{\prime \prime}$ & $146.11, \mathrm{~d},{ }^{1} J_{\mathrm{C}-\mathrm{F}}=259.1$ & $14.64, \mathrm{~s}$ & \multirow{2}{*}{$\begin{array}{l}\mathrm{C} 2 ", \mathrm{C}{ }^{\prime \prime} 7.73, \mathrm{t}, 2 \mathrm{C} \\
{ }^{1} J_{\mathrm{C}-\mathrm{H}}=165.9\end{array}$} \\
\hline $3^{\prime \prime}$ & $\begin{array}{l}104.88, \mathrm{dd}, \\
{ }^{2} J_{\mathrm{C}-\mathrm{F}}=24.2 \text { and } 27.3\end{array}$ & - & \\
\hline $4^{\prime \prime}$ & $157.33, \mathrm{~d},{ }^{1} J_{\mathrm{C}-\mathrm{F}}=252.55$ & - & - \\
\hline $5^{\prime \prime}$ & $112.32, \mathrm{dd}{ }^{2} J_{\mathrm{C}-\mathrm{F}}=3.3$ & - & - \\
\hline $6^{\prime \prime}$ & $110.77, \mathrm{~d},{ }^{2} J_{\mathrm{C}-\mathrm{F}}=3.4$ & - & - \\
\hline $\mathrm{CH}_{3}{ }^{\mathrm{a}}$ & $31.33, \mathrm{~s}$ & $35.31, \mathrm{~s}$ & - \\
\hline
\end{tabular}

a $\mathrm{CH}_{3}$ in mesylate moiety, $\mathrm{s}-$ singlet, $\mathrm{d}$ - doublet, $\mathrm{dd}$ - doublet of doublets, $\mathrm{t}-$ triplet, $\mathrm{td}-$ triplet of doublets, $\mathrm{m}$ - multiplet

ical shifts for the basic fluoroquinolone moiety, including the corresponding C11, was further used as an additional ${ }^{13} \mathrm{C}-\mathrm{NMR}$ parameter in correlation with computed molecular descriptors (MDs) and drug-likeness scores (DLSs). 
M. Jadrijević-Mladar Takač: Effects of substituents on the NMR features of basic bicyclic ring systems of fluoroquinolone antibiotics and the relationships between NMR chemical shifts, molecular descriptors and drug-likeness parameters, Acta Pharm. 60 (2010) $237-254$.

\section{Correlation studies}

The selected ${ }^{1} \mathrm{H}$ - and ${ }^{13} \mathrm{C}-\mathrm{NMR}$ chemical shifts $(\delta / \mathrm{ppm})$ of $\mathrm{H}$ and $\mathrm{C}$ atoms, belonging to basic fluoronaphthyridone and fluoroquinolone moieties, including atoms in $\mathrm{COOH}$ and $\mathrm{NH}_{n}{ }^{+}$(Table IV), and the MDs, i.e., the lipophilicity parameter (miLog $P$ ), the topological polar surface area (TPSA), the relative molecular mass $\left(M_{\mathrm{r}}\right)$ and the volume $(V)$, as well as DLSs for specific biological activity, i.e., the $\mathrm{G}$ protein-coupled receptor ligand likeness (GPCR ligand-ls), the ion channel modulator likeness (ICM-ls), the kinase inhibitor likeness (KI-ls) and the nuclear receptor ligand likeness (NRL-ls) (Table V), were used in the study.

MDs and DLSs were calculated for the monocharged cations of investigated fluoroquinolone salts, i.e., the pefloxacin cation $\left(\mathrm{PFXH}^{+}\right)$, where tertiary $\mathrm{N}^{\prime}$ ' in methylpiperazine ring is protonated $\left(\mathrm{RR}^{\prime} \mathrm{R}^{\prime \prime} \mathrm{NH}^{+}\right)$, the ciprofloxacin cation $\left(\mathrm{CIPH}^{+}\right)$with positive charge at $\mathrm{N}^{\prime}$, where the secondary amino group in piperazine ring at $\mathrm{N}^{\prime}$ is protonated (RR' $\mathrm{NH}_{2}^{+}$), and for trovafloxacin cation $\left(\mathrm{TVAH}^{+}\right)$, where the primary amino group at position $\mathrm{C}^{\prime}$ is protonated $\left(\mathrm{RNH}_{3}{ }^{+}\right)$. Thus, the investigated fluoroquinolone salts were represented as primary, secondary or tertiary amine salts.

Relationships between the selected NMR chemical shifts $(\delta, \mathrm{ppm})$, MDs and DLSs, as well as the collinearity parameters are shown in Table VI. In general, the ${ }^{13} \mathrm{C}-\mathrm{NMR}$ chemical shifts $(\delta, \mathrm{ppm})$ showed collinearities with more investigated MDs and DLSs than the selected ${ }^{1} \mathrm{H}-\mathrm{NMR}$ chemical shifts $(\delta$, ppm).

\section{${ }^{1} H-N M R$ chemical shift correlations}

Among investigated ${ }^{1} \mathrm{H}-\mathrm{NMR}$ chemical shifts collinearities were revealed with $\delta / \mathrm{ppm}$ of $\mathrm{H} 5, \mathrm{H}$ in $\mathrm{COOH}$ and $\mathrm{NH}_{n}{ }^{+}$, while the $\mathrm{H} 2 \delta / \mathrm{ppm}$ showed no collinearity with the investigated DSs and DLSs.

Chemical shifts of $\mathrm{H} 5$, increased in the order $\mathrm{CIPH}^{+}, \mathrm{PFXH}^{+}$to $\mathrm{TVAH}^{+}$and collinear relationships with miLog $P$ and KI-ls $(R=0.9962$ and $R=0.9969$, respectively), were revealed. However, the ${ }^{1} \mathrm{H}-\mathrm{NMR}$ chemical shifts of protons in $\mathrm{COOH}$ and $\mathrm{NH}_{n}{ }^{+}$showed the upfield chemical shift in the order $\mathrm{PFXH}^{+}, \mathrm{CIPH}^{+}$to $\mathrm{TVAH}^{+}$, which is in line with types of salts, i.e., tertiary, secondary and primary amine salts, and collinearities between

Table IV. Selected ${ }^{1} \mathrm{H}$ - and ${ }^{13} \mathrm{C}$-NMR chemical shifts of the corresponding fluoroquinolone salts used in correlatons with molecular descriptors (MDs) and drug-likeness scores (DLSs)

\begin{tabular}{ccccccccc}
\hline & \multicolumn{7}{c}{ Selected NMR chemicl shifts $(\delta$, ppm $)$} \\
\cline { 2 - 9 } Compd. & \multicolumn{7}{c}{${ }^{13}$ C-NMR } & \multicolumn{5}{c}{${ }^{1} \mathrm{H}-\mathrm{NMR}$} \\
\cline { 2 - 9 } & $\mathrm{C} 2$ & $\mathrm{C} 4$ & $\mathrm{C} 5$ & $\mathrm{C} 11$ & $\mathrm{COOH}$ & $\mathrm{NH}_{n}{ }^{+}$ & $\mathrm{H} 2$ & $\mathrm{H} 5$ \\
\hline CIP HCl & 148.28 & 176.45 & 111.27 & 165.94 & 15.14 & 9.55 & 8.69 & 7.95 \\
PFX Mes & 148.86 & 176.24 & 111.52 & 166.13 & 15.28 & 9.87 & 8.98 & 7.97 \\
TVA Mes & 148.02 & 177.05 & 117.88 & 165.38 & 15.06 & 8.18 & 8.83 & 8.07 \\
\hline
\end{tabular}


M. Jadrijević-Mladar Takač: Effects of substituents on the NMR features of basic bicyclic ring systems of fluoroquinolone antibiotics and the relationships between NMR chemical shifts, molecular descriptors and drug-likeness parameters, Acta Pharm. 60 (2010) $237-254$.

Table V. Calculated molecular descriptors (miLogP, TPSA, $\mathrm{M}_{r}$ and V) and drug-likeness scores (GPCR ligand-ls, ICM-ls, KI-ls and NRL-ls) for monoprotonated cations of investigated fluoroquinolone salts

\begin{tabular}{ccccccccc}
\hline & \multicolumn{3}{c}{ Molecular descriptors (MDs) } & \multicolumn{3}{c}{ Drug-likeness scores (DLSs) } \\
\cline { 2 - 9 } Cation & miLogP & TPSA & $M_{\mathrm{r}}$ & $V$ & $\begin{array}{c}\text { GPCR } \\
\text { ligand-ls }\end{array}$ & ICM-ls & KI-ls & NRL-ls \\
\hline $\mathrm{CIPH}^{+}$ & -3.365 & 79.147 & 332.355 & 286.436 & 0.11 & 0.45 & -0.30 & -0.73 \\
$\mathrm{PFXH}^{+}$ & -3.255 & 66.978 & 334.371 & 299.289 & -0.07 & 0.21 & -0.27 & -0.81 \\
$\mathrm{TVAH}^{+}$ & -1.936 & 103.076 & 417.367 & 328.708 & -0.02 & -0.23 & 0.05 & -0.53 \\
\hline
\end{tabular}

miLog $P$ - lipophilicity parameter, TPSA - total polar surface area, $M_{\mathrm{r}}$ - relative molar mass, $V$ - volume, GPCR ligand-ls - G protein-coupled receptor ligand likeness score, ICM-ls - ion channel modulator likeness, KI-ls - kinase inhibitor likeness score

Table VI. Investigated collinearities between ${ }^{1} \mathrm{H}$ - and ${ }^{13} \mathrm{C}-\mathrm{NMR}$ chemical shifts $(\delta$, ppm), molecular descriptors (TPSA, miLogP, $\mathrm{M}_{r}$ and $\mathrm{V}$ ) and computed drug-likeness scores with drugs of known biological activity, GPCR ligand-ls, ICM-ls, KI-ls and NRL-ls

\begin{tabular}{|c|c|c|c|c|c|c|}
\hline No. & Parameter 1 & Parameter 2 & $Y=A+B x$ & $R$ & SD & $P$ \\
\hline 1 & $\operatorname{miLog} P$ & $M_{\mathrm{r}}$ & $Y=535.1466+60.9335 X$ & 0.9988 & 3.3219 & 0.0308 \\
\hline 2 & $\operatorname{miLog} P$ & TPSA & $Y=143.5583+21.2102 X$ & 0.9184 & 10.2792 & 0.2590 \\
\hline 3 & ${ }^{1} \mathrm{H} \delta, \mathrm{ppm} \mathrm{COOH}$ & TPSA & $Y=15.6345-0.0057 X$ & 0.9421 & 0.0528 & 0.2178 \\
\hline 4 & ${ }^{1} \mathrm{H} \delta, \mathrm{ppm} \mathrm{COOH}$ & NRL-ls & $Y=17.4042-1.1936 X$ & -0.9216 & 0.0792 & 0.2539 \\
\hline 5 & ${ }^{13} \mathrm{C} \delta, \mathrm{ppm} \mathrm{C} 11$ & TPSA & $Y=167.5729-0.0211 X$ & -0.9958 & 0.0504 & 0.0503 \\
\hline 6 & ${ }^{13} \mathrm{C} \delta$,ppm C11 & ICM-ls & $Y=-120.7745+0.7292 X$ & 0.8245 & 0.2760 & 0.3829 \\
\hline 7 & ${ }^{13} \mathrm{C} \delta$, ppm C11 & KI-ls & $Y=78.0452-0.4717 X$ & -0.9481 & 0.0872 & 0.2060 \\
\hline 8 & ${ }^{13} \mathrm{C} \delta$, ppm C11 & NRL-ls & $Y=60.6051-0.3697 X$ & -0.9994 & 0.0071 & 0.0222 \\
\hline 9 & ${ }^{13} \mathrm{C} \delta, \mathrm{ppm} \mathrm{C4}$ & TPSA & $Y=174.6856+0.0228 X$ & 0.9964 & 0.0506 & 0.0543 \\
\hline 10 & ${ }^{13} \mathrm{C} \delta$, ppm C4 & $\operatorname{miLog} P$ & $Y=178.0103+0.5015 X$ & 0.9487 & 0.1880 & 0.2048 \\
\hline 11 & ${ }^{13} \mathrm{C} \delta, \mathrm{ppm} \mathrm{C} 4$ & $M_{\mathrm{r}}$ & $Y=173.5648+0.0083 X$ & 0.9629 & 0.1604 & 0.1740 \\
\hline 12 & ${ }^{13} \mathrm{C} \delta$, ppm C4 & $\mathrm{V}$ & $Y=171.6466+0.0162 X$ & 0.8547 & 0.3086 & 0.3475 \\
\hline 13 & ${ }^{13} \mathrm{C} \delta$, ppm C4 & KI-ls & $Y=-77.27094+0.4366 X$ & 0.9461 & 0.0889 & 0.2100 \\
\hline 14 & ${ }^{13} \mathrm{C} \delta$, ppm C4 & NRL-ls & $Y=-61.2489+0.3429 X$ & 0.9996 & 0.0058 & 0.0182 \\
\hline 15 & ${ }^{1} \mathrm{H} \delta, \mathrm{ppm} \mathrm{H} 5$ & $\operatorname{miLog} P$ & $Y=8.2264+0.0806 X$ & 0.9962 & 0.0079 & 0.0554 \\
\hline 16 & ${ }^{1} \mathrm{H} \delta$, ppm H5 & KI-ls & $Y=-24.2278+3.0081 X$ & 0.9969 & 0.0216 & 0.0502 \\
\hline 17 & ${ }^{13} \mathrm{C} \delta$, ppm C5 & $\operatorname{miLog} P$ & $Y=126.9841+4.7081 X$ & 0.9994 & 0.1899 & 0.0228 \\
\hline 18 & ${ }^{13} \mathrm{C} \delta, \mathrm{ppm} \mathrm{C5}$ & KI-ls & $Y=-6.0481+0.0517 X$ & 0.9990 & 0.0121 & 0.0280 \\
\hline 19 & ${ }^{13} \mathrm{C} \delta, \mathrm{ppm} \mathrm{C} 5$ & NRL-ls & $Y=130.6010+24.7019 X$ & 0.9510 & 1.6384 & 0.2002 \\
\hline 20 & ${ }^{1} \mathrm{H} \delta, \mathrm{ppm} \mathrm{NH}_{n}{ }^{+}$ & TPSA & $Y=13.2095+0.0483 X$ & -0.9875 & 0.2004 & 0.1009 \\
\hline 21 & ${ }^{1} \mathrm{H} \delta, \mathrm{ppm} \mathrm{NH}_{n}{ }^{+}$ & NRL-ls & $Y=0.7804-0.1598 X$ & -0.9948 & 0.0207 & 0.0648 \\
\hline 22 & ${ }^{1} \mathrm{H} \delta, \mathrm{ppm} \mathrm{NH}_{n}{ }^{+}$ & ICM-ls & $Y=-2.8978+0.3306 X$ & 0.8605 & 0.2485 & 0.3403 \\
\hline
\end{tabular}

TPSA - topological polar surface area, miLog $P$ - $\log$ arithm of partition coefficient, $M_{\mathrm{r}}$ - relative molecular mass, G protein-coupled receptor-likeness score (GPCR ligand-ls), ion channel modulator-likeness (ICM-ls), kinase inhibitor-likeness (KI-ls) and nuclear receptor ligand-likeness (NRL-ls) 
M. Jadrijević-Mladar Takač: Effects of substituents on the NMR features of basic bicyclic ring systems of fluoroquinolone antibiotics and the relationships between NMR chemical shifts, molecular descriptors and drug-likeness parameters, Acta Pharm. 60 (2010) $237-254$.

the ${ }^{1} \mathrm{H}-\mathrm{NMR}$ chemical shift of $\mathrm{H}$ in $\mathrm{COOH}$ and $\mathrm{NH}_{n}{ }^{+}$with TPSA $(R=-0.9421$ and $\mathrm{R}=-0.9875$, respectively) and with NRL-ls $(R=-0.9216$ and $R=-0.9948$, respectively) were revealed (Table VI).

In the investigated relationships, using the selected ${ }^{1} \mathrm{H}-\mathrm{NMR}$ chemical shifts, the influence of substituents at positions $1\left(R^{1}\right)$ and $7\left(R^{2}\right)$, as well as $X 8=N$, on the chemical shifts of $\mathrm{H} 5$ was observed, so that the experimental parameters are in collinear relationships with the miLogP and KI-ls. Significant differences in $\mathrm{TVAH}^{+}$parameters, compared to $\mathrm{PFXH}^{+}$and $\mathrm{CIPH}^{+}$parameters, were also observed.

\section{${ }^{13} \mathrm{C}-\mathrm{NMR}$ chemical shift correlations}

The ${ }^{13} \mathrm{C}$-NMR chemical shifts of selected $\mathrm{C}$ atoms, which belong to the basic bicyclic fluoronaphthyridone and fluoroquinolone systems, C4, C5 and C11 from the $\mathrm{COOH}$ group, showed collinearities with MDs and DLSs. Thus, the ${ }^{13} \mathrm{C}$ NMR chemical shifts of C4, C5 and C11 showed collinearities with TPSA, miLogP, as well as with KI-ls and NRL-ls, while the C2 $\delta$, ppm showed no collinearities in correlations with the investigated MDs and DLSs.

In addition to findings for ${ }^{1} \mathrm{H}-\mathrm{NMR}$ of $\mathrm{H} 5$, the ${ }^{13} \mathrm{C}-\mathrm{NMR}$ chemical shifts of $\mathrm{C} 5$ showed also collinearities with miLogP and KI-ls $(R=0.9994$ and $R=0.9990$, respectively). Due to impact of substituents in $\mathrm{TVAH}^{+}$, the $\delta$, ppm of $\mathrm{C} 5$ significantly differs from $\mathrm{C} 5$ in $\mathrm{PFXH}^{+}$and $\mathrm{CIPH}^{+}$, as well as in relative drug-likeness score for KI-ls. Similarly to findings for $\mathrm{H} 5$ and $\mathrm{C} 5$, in their collinearities with $\operatorname{miLog} P$ and $\mathrm{KI}-1 \mathrm{~s}$, the $\mathrm{H}$ in $\mathrm{COOH} \delta$, ppm and $\mathrm{C} 11 \delta$, ppm revealed collinearities with TPSA and NRL-ls $(R=-0.9958$ and $R=-0.9994$, respectively); however, the $\delta$, ppm of $\mathrm{H}$ in $\mathrm{COOH}$ showed no significance in correlations with TPSA and NRL-ls (Table VI).

Among the chemical shifts used in this investigation, the $\mathrm{C} 4 \delta$, ppm showed collinearities with different MDs and DLSs, i.e., TPSA, miLogP, $M_{\mathrm{r}}$, NRL-ls and KI-ls. Thus, the following collinearities were revealed with TPSA and NRL-ls $(R=0.9964$ and $R=$ 0.9996 , respectively) while the other collinear relationships were with miLog $P$, KI-ls and $M_{\mathrm{r}}(R=0.9487, R=0.9461$ and $R=0.9629$, respectively) (Table VI).

The investigated ${ }^{1} \mathrm{H}$ - and ${ }^{13} \mathrm{C}-\mathrm{NMR}$ chemical shifts in correlations with volume $(V)$ and other DLSs (ICM-ls and GPCR-ligand-ls) showed no collinearities. The only collinear relationship with GPCR ligand-ls was revealed with an average ${ }^{13} \mathrm{C}-\mathrm{NMR}$ chemical shift of the basic bicyclic ring systems (FQbbrs), $R=0.9873$ ). FQbbrs was obtained by sum-

Table VII. Investigated relationships of molecular descriptors (MDs) and drug-likeness scores (DLSs) with the corresponding ${ }^{1} \mathrm{H}$ and ${ }^{13} \mathrm{C}$ chemical shifts

\begin{tabular}{ccc}
\hline MDs or DLs & ${ }^{1} \mathrm{H}-\mathrm{NMR}$ & ${ }^{13} \mathrm{C}-\mathrm{NMR}$ \\
\hline TPSA & $\mathrm{NH}_{n}{ }^{+}, \mathrm{H}$ in $\mathrm{COOH}$ & $\mathrm{C} 4$ and $\mathrm{C} 11$ \\
miLogP & $\mathrm{H} 5$ & $\mathrm{C} 4$ and $\mathrm{C} 5$ \\
NRL-ls & $\mathrm{NH}_{n}{ }^{+}$and $\mathrm{H}$ in $\mathrm{COOH}$ & $\mathrm{C} 4, \mathrm{C} 5$ and $\mathrm{C} 11$ \\
KI-ls & $\mathrm{H}$ in COOH and $\mathrm{H} 5$ & $\mathrm{C} 4, \mathrm{C} 5$ and $\mathrm{C} 11$ \\
\hline
\end{tabular}


M. Jadrijević-Mladar Takač: Effects of substituents on the NMR features of basic bicyclic ring systems of fluoroquinolone antibiotics and the relationships between NMR chemical shifts, molecular descriptors and drug-likeness parameters, Acta Pharm. 60 (2010) $237-254$.

ming up all signal lines that belong to fluoronaphthyridone or fluoroquinolone $\mathrm{C}$ atoms (C2 to $\mathrm{C} 10$ ) including $\mathrm{C} 11$ from carboxylic group, and by dividing the resulting sum by the number of lines ( $\Sigma$ of ppm of all signal lines $C 2-C 10$ and $C 11 / n$ of signal lines).

The overall findings of investigations of the relationships between MD and DLS with the corresponding ${ }^{1} \mathrm{H}$ - and ${ }^{13} \mathrm{C}-\mathrm{NMR}$ chemical shifts are given in Tables VI and VII, and schematically in Fig. 4, while the corresponding ${ }^{1} \mathrm{H}$ - and ${ }^{13} \mathrm{C}-\mathrm{NMR}$ chemical shifts in relationships with a particular fluoroquinolone salt (primary, secondary or tertiary amine salt) are displayed in Table VIII.

The change in TPSA of investigated fluoroquinolone salts affects the ${ }^{1} \mathrm{H}-\mathrm{NMR}$ chemical shifts of $\mathrm{NH}_{n}{ }^{+}$and $\mathrm{H}$ in $\mathrm{COOH}$, as well as the ${ }^{13} \mathrm{C}-\mathrm{NMR}$ chemical shifts of $\mathrm{C} 4$ and $\mathrm{C} 11$, the atoms included in keto-carboxyilic moiety responsible for the fluoroquinolone binding site. The order of chemical shifts, $\mathrm{PFXH}^{+}>\mathrm{CIPH}^{+}>\mathrm{TVAH}^{+}$was observed for $\mathrm{NH}_{n}{ }^{+}$protons (i.e., 9.87, 9.56 and 8.18, respectively) as well as for the corresponding proton in their $\mathrm{COOH}$ groups (i.e., 15.28, 15.14 and 15.06), indicating upfield shifts of these protons from tertiary, secondary to primary amine salts. The same order, i.e., $\mathrm{PFXH}^{+}>$ $\mathrm{CIPH}^{+}>\mathrm{TVAH}^{+}$(tertiary > secondary > primary amine salt) was revealed for NRL-ls. In conclusion, the type of salt and TPSA have an important role for the fluoroquinolone binding site and NRL-ls of investigated fluoroquinolone salts.

Collinear relationships were also revealed between miLog $P$ and ${ }^{1} \mathrm{H}-\mathrm{NMR}$ chemical shifts of $\mathrm{H} 5$ and ${ }^{13} \mathrm{C}-\mathrm{NMR}$ chemical shifts of $\mathrm{C} 5$. While the downfield shift was observed for $\mathrm{H} 5$, in the order $\mathrm{TVAH}^{+}>\mathrm{CIPH}^{+}>\mathrm{PFXH}^{+}$(i.e., primary $>$secondary $>$tertiary amine salt), the ${ }^{13} \mathrm{C}-\mathrm{NMR}$ chemical shifts of $\mathrm{C} 5$ were in the order $\mathrm{TVAH}^{+}>\mathrm{PFXH}^{+}>\mathrm{CIPH}^{+}$ (primary $>$ tertiary $>$ secondary amine salt). However, the ${ }^{1} \mathrm{H}$ - and ${ }^{13} \mathrm{C}-\mathrm{NMR}$ chemical shifts of $\mathrm{H} 5$ and $\mathrm{C} 5$ showed collinearities with KI-ls. Therefore, regardless of the order related to the type of salt, the NMR chemical shifts of $\mathrm{H} 5$ and $\mathrm{C} 5$ could be useful in further correlation studies with miLogP and KI-ls of fluoroquinolone antibiotics.

Findings in this study showed differences in experimental and computed parameters for TVA mesylate in comparison with PFX mesylate and CIP hydrochloride, which could be related to different side-effect profiles of these fluoroquinolones.

Table VIII. Chemical shifts $(\delta, p p m)$ in relationships with fluoroquinolone type of amine salt

\begin{tabular}{clc}
\hline $\begin{array}{c}{ }^{1} \mathrm{H}-\text { or }{ }^{13} \mathrm{C}-\mathrm{NMR} \\
\delta, \mathrm{ppm}\end{array}$ & $\begin{array}{c}\text { Chemical shift }(\delta, \mathrm{ppm}) \\
\text { decreasing }\end{array}$ & $\begin{array}{c}\text { Type od amine salt } \\
\left(\mathrm{RNH}_{3}{ }^{+}, \mathrm{RR}^{\prime} \mathrm{NH}_{2}{ }^{+}, \mathrm{RR}^{\prime} \mathrm{R}^{\prime \prime} \mathrm{NH}^{+}\right)\end{array}$ \\
\hline $\mathrm{NH}_{n}{ }^{+}$ & $\mathrm{PFXH}^{+}>\mathrm{CIPH}^{+}>\mathrm{TVAH}^{+}$ & tertiary $>$secondary $>$primary \\
$\mathrm{H} 5$ & $\mathrm{TVAH}^{+}>\mathrm{PFXH}^{+}>\mathrm{CIPH}^{+}$ & primary $>$tertiary $>$secondary \\
$\mathrm{H}$ in $\mathrm{COOH}$ & $\mathrm{PFXH}^{+}>\mathrm{CIPH}^{+}>\mathrm{TVAH}^{+}$ & tertiary $>$secondary $>$primary \\
$\mathrm{C} 4$ & $\mathrm{TVAH}^{+}>\mathrm{CIPH}^{+}>\mathrm{PFXH}^{+}$ & primary $>$secondary $>$tertiary \\
$\mathrm{C} 5$ & $\mathrm{TVAH}^{+}>\mathrm{PFXH}^{+}>\mathrm{CIPH}^{+}$ & primary $>$tertiary $>$secondary \\
$\mathrm{C} 11$ & $\mathrm{PFXH}^{+}>\mathrm{CIPH}^{+}>\mathrm{TVAH}^{+}$ & tertiary $>$secondary $>$primary \\
\hline
\end{tabular}




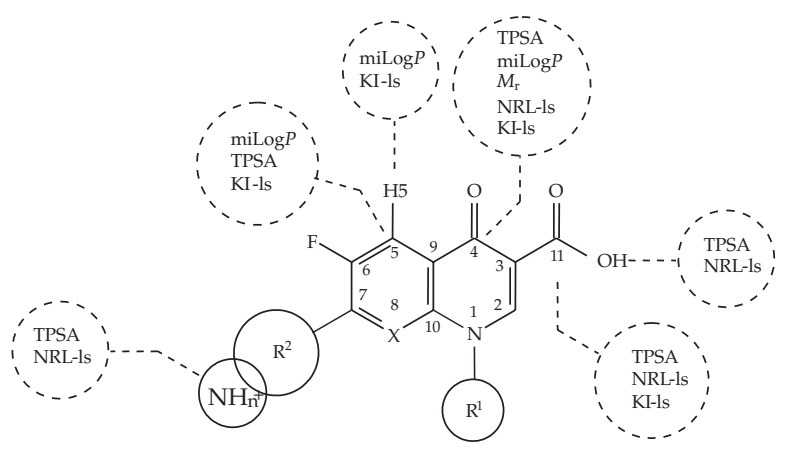

Fig. 4. The shematic display of investigated fluoroquinolone salt structures with marked $\mathrm{H}$ and $\mathrm{C}$ atoms whose ${ }^{1} \mathrm{H}$ - and ${ }^{13} \mathrm{C}-\mathrm{NMR}$ chemical shifts showed collinear relationships $[(R=\delta(0.9-1.0)]$ with the corresponding MDs and DLSs.

\section{CONCLUSIONS}

By correlating ${ }^{1} \mathrm{H}$ - and ${ }^{13} \mathrm{C}-\mathrm{NMR}$ chemical shifts of $\mathrm{H}$ and $\mathrm{C}$ atoms of fluoroquinolones basic ring systems with calculated molecular descriptors $M_{r}$, TPSA, miLogP and $V$ ), as well as with drug-likeness scores (GPCR, ICL-ls, KI-ls and NRL-ls) computed for monoprotonic cations of investigated fluoroquinolone salts $\left(\mathrm{TVAH}^{+}, \mathrm{PFXH}^{+}\right.$and $\left.\mathrm{CIPH}^{+}\right)$, collinear relationships were revealed between investigated parameters.

The ${ }^{13} \mathrm{C}-\mathrm{NMR}$ chemical shifts of $\mathrm{C} 4, \mathrm{C} 5$ and $\mathrm{C} 11$ and the ${ }^{1} \mathrm{H}-\mathrm{NMR}$ chemical shifts of $\mathrm{COOH}, \mathrm{H} 5$ and $\mathrm{NH}_{n}{ }^{+}$protons proved to be good parameters in exploration of property-property and property-drug-likeness relationships between investigated fluoroquinolone salts. Thus, collinearities between ${ }^{13} \mathrm{C}-\mathrm{NMR}$ chemical shifts of C4, C5 and C11 and KI-ls and NRL-ls, respectively in addition to TPSA, miLog $P$ and $M_{\mathrm{r}}$ were revealed, while the ${ }^{1} \mathrm{H}-\mathrm{NMR}$ chemical shifts of $\mathrm{COOH}, \mathrm{H} 5$ and $\mathrm{NH}_{n}{ }^{+}$protons showed collinearity with TPSA and miLogP, as well as with KI-ls, NRL-ls and GPCR ligand-ls.

Although significant collinearities between the investigated parameters of these fluoroquinolones were revealed, the findings of this study also showed differences in experimental and computed parameters for TVA mesylate in comparison with PFX mesylate and CIP hydrochloride, which could be related to different side-effect profiles of these fluoroquinolones.

For the use of NMR parameters in prediction of relationships either with MDs or DLSs with the aim of predicting the biological activity or safety profiles of fluoroquinolone antibiotics, more fluoroquinolone antibiotics should be included into investigation.

Acronyms. - APT - attached proton test; CIP - ciprofloxacin; $\mathrm{CIPH}^{+}-$monoprotonated ciprofloxacin cation; CNS - central nervous system; COSY - correlated spectroscopy; DLS - drug-likeness score; DMSO- $d_{6}$ - deuterated dimethylsulfoxide; FQ - fluoroquinolone; GPCR ligand - G protein-coupled receptor ligand; GPCR ligand-ls - GPCR ligand likeness score; HECTOR - heteronuclear chemical shift correlation; ICM - ion channel modulator; ICM-ls - ion channel ligand likeness score; KI - kinase inhibitor; KI-ls - kinase inhibitor likeness score; $\mathrm{MD}$ - molecular descriptor; miLog $P$ - molinspiration loga- 
M. Jadrijević-Mladar Takač: Effects of substituents on the NMR features of basic bicyclic ring systems of fluoroquinolone antibiotics and the relationships between NMR chemical shifts, molecular descriptors and drug-likeness parameters, Acta Pharm. 60 (2010) $237-254$.

rithm of lipophilicity; $M_{\mathrm{r}}$ - relative molecular mass; NMR - nuclear magnetic resonance; NOESY - nuclear Overhauser and exchange spectroscopy; NRL - nuclear receptor ligand; NRL-ls - nuclear receptor ligand likeness score; PFX - pefloxacin; $\mathrm{PFXH}^{+}-$ monoprotonated pefloxacin cation; $\mathrm{P}$ - statistical parameter; $R$ - coefficient correlation; RNA - ribonucleic acid; QSAR - quantitative structure activity relationship; QTc interval - a measure of the time between the start of the $Q$ wave and the end of the $T$ wave in the heart's electrical cycle; SD - standard deviation; TPSA - topological polar surface area; TVA - trovafloxacin; $\mathrm{TVAH}^{+}-$monoprotonated trovafloxacin cation; V - volume.

Acknowledgements. - Many thanks to Professor Dražen Vikić-Topić for his valuable discussion in NMR spectra elucidation and to the NMR Centre of Ruđer Bošković Institute for their support in NMR spectra recording, as well as to the pharmaceutical industries (Lek, Krka and Pfizer) for their kind donations of investigated fluoroquinolones. Thanks to the Ministry of Science, Education and Sports of the Republic of Croatia, Grant No. 098-0982929-2940, for financial support.

\section{REFERENCES}

1. P. C. Appelbaum and P. A. Hunter, The fluoroquinolone antibacterials: past, present and future perspectives, Int. J. Antimicrob. Agents 16 (2000) 5-15; DOI: 10.1016/S0924-8579(00)00192-8.

2. D. C. Hooper, Quinolone Antimicrobial Agents (Eds. D. C. Hooper and E. Rubinstein), AMS Press, Washington 2003, pp. 3-40.

3. S. Emami, A. Shafiee and A. Foroumadi, Structural features of new quinolones and relationship to antibacterial activity against Gram-positive bacteria, Mini Rev. Med. Chem. 6 (2006) 375-386; DOI: $10.2174 / 138955706776361493$.

4. K. E. Brighty and T. D. Gootz, The chemistry and biological profile of trovafloxacin, J. Antimicrob. Chemother. 39 (1997) 1-14; DOI: 10.1093/jac/39.suppl_2.1.

5. M. P. Montanari, M. Prenna, M. Mingoia, S. Ripa and P. E. Varaldo, In vitro antibacterial activity of trovafloxacin and five other fluoroquinolones, Chemotherapy 44 (1998) 85-93; DOI: 10.1159/ 000007097.

6. J. Vincent, R. Teng, D. K. Dalvie and H. L. Friedman, Pharmacokinetics and metabolism of single oral doses of trovafloxacin, Am. J. Surg. 176 (1998) 8S-13S; DOI: 10.1016/S0002-9610(98) 00213-X.

7. D. Scuster, C. Laggner and T. Lagner, Why drugs fail - A Study on Side Effects in New Chemical Entities, in Antitargets. Prediction and Prevention of Drug Side Effects (Ed. R. Vaz and T. Klabunde), Wiley WCH Verlag GmbH \& Co. KGaA, Weinheim 2008, pp. 3-22.

8. M. J. Liguori, M. G. Anderson, S. Bukofzer, J. McKim, J. F. Pregenzer, J. Retief, B. B. Spear and J. F. Waring, Microarray analysis in human hepatocytes suggests a mechanism for hepatotoxicity induced by trovafloxacin, Hepatology 41 (2005) 177-186; DOI: 10.1124/jpet.105.096347.

9. Q. Sun, R. Zhu, F. W. Foss, Jr. and T. L. Macdonald, Mechanisms of trovafloxacin hepatotoxicity: studies of a model cyclopropylamine-containing system, Bioorg. Med. Chem. Lett. 17 (2007) 6682-6686; DOI: 10.1016/j.bmd.2007.10.070.

10. Q. Sun, R. Zhu, F. W. Foss, Jr. and T. L. Macdonald, In vitro metabolism of a model cyclopropylamine to reactive intermediate: Insights into trovafloxacin-induced hepatotoxicity, Chem. Res. Toxicol. 21 (2008) 711-719; DOI: 10.1021/tx7003085.

11. J. M. Domagala, Structure-activity and structure-side-effect relationships for the quinolone antibacterials, J. Antimicrob. Chemother. 33 (1994) 685-706; DOI: 10.1093/jac/33.4.685.

12. G. S. Tillotson, Quinolones: structure-activity relationships and future predictions, J. Med. Microb. 44 (1996) 320-324; DOI: 10.1099/00222615-44-5-320. 
M. Jadrijević-Mladar Takač: Effects of substituents on the NMR features of basic bicyclic ring systems of fluoroquinolone antibiotics and the relationships between NMR chemical shifts, molecular descriptors and drug-likeness parameters, Acta Pharm. 60 (2010) 237-254.

13. L. Mandell and G. Tillotson, Fluoroquinolone safety: An overview evaluating safety and antimicrobial activity profiles based on molecular structure categorized adverse effects, Can. J. Infec. Dis. 13 (2002) 54-61.

14. Y. Tsuzuki, K. Tomita, K. Shibamori, Y. Sato, S. Kashimoto and K. Chiba, Synthesis and structure-activity relationships of novel 7-substituted 1,4 dihydro-4-oxo-1-(2-thiazolyl)-1,8-naphthyridine-3-carboxylic acids as anti-tumor agents, part-2, J. Med. Chem. 47 (2004) 2097-2109; DOI: 10.1021/jm0304966.

15. M. Paul, A. Gafter-Gvili, A. Fraser and L. Leibovici, The anti-cancer effects of quinolone antibiotics?, Eur. J. Clin. Microbiol. Infect. Dis. 26 (2007) 825-831; DOI: 10.1007/s10096-007-0375-4.

16. T. Norris and G. Ferry, Process for Preparing Quinolone and Naphthyridine Carboxylic Acids, U.S. Pat. 6,114,531, 5 Sep. 2005.

17. E. Rubinstein, History of quinolones and their side-effects, Chemotherapy 47 (2001) 3-8; 44-48; DOI: $10.1159 / 000057838$.

18. P. J. Shaw, A. M. Fullerton, M. A. Scott, P. E. Ganey and R. A. Roth, The role of the hemostatic system in murine liver injury induced by coexposure to lipopolysaccharide and trovafloxacin, a drug with idiosyncratic liability, Toxicol. Appl. Pharmacol. 236 (2009) 293-300; DOI: 10.1016/j. taap. 2009.01.018.

19. C. A. Lipinski, F. Lombardo, B. W. Dominy and P. J. Feeney, Experimental and computational approaches to estimate solubility and permeability in drug discovery and development settings, Adv. Drug Del. Rev. 23 (1997) 4-25; DOI: 10.1016/S0169-409X(00)00129-0.

20. D. F. Veber, S. R. Johnson, H. Y. Cheng, B. R. Smith, K. W. Ward and K. D. Kopple, Molecular properties that influence the oral bioavailability of drug candidates, J. Med. Chem. 45 (2002) 2615-2623; DOI: 10.1021/jm020017n.

21. P. Ertl, B. Rohde and P. Selzer, Fast calculation of molecular polar surface area as a sum of fragent-based contributions and its application to the prediction of drug transport properties, J. Med. Chem. 43 (2000) 3714-3717; DOI: 10.1021/jm000942e.

22. H. O. Kalinowski, S. Berger and S. Braun, ${ }^{13}$ C-NMR Spektroskopie, Georg Thieme Verlag, Stuttgart 1984.

23. R. M. Silverstein, C. C. Bassler and T. C. Morrill, Spectroscopic Identification of Organic Compounds, 5th ed., Wiley, New York 1991.

24. G. Fardella, P. Barbetti, I. Chiappini and G. Grandolini, Quantitative analysis of fluoroquinolones by ${ }^{1} \mathrm{H}$ and ${ }^{19} \mathrm{~F}-\mathrm{NMR}$ spectroscopy, Int. J. Pharm. 121 (1995) 123-127; DOI: 10:1016/03785173(95)00038-K.

25. A. Zieba, A. Mašlankiewicz and J. Sitkovski, ${ }^{1} \mathrm{H},{ }^{13} \mathrm{C}$ and ${ }^{15} \mathrm{~N}$ NMR spectra of ciprofloxacin, Magn. Reson. Chem. 42 (2004) 903-904; DOI: 10.1002/mrc.1468.

\section{$S A \check{Z} E T A K$}

\section{Utjecaj supstituenata na NMR značajke temeljnog bicikličkog prstenastog sustava fluorokinolonskih antibiotika i odnos između NMR kemijskih pomaka, molekulskih opisivača i parametara sličnosti s lijekovima}

MILENA JADRIJEVIĆ-MLADAR TAKAČ

U radu je opisano ispitivanje NMR spektroskopskih značajki trovafloksacin (TVA) mesilata, pefloksacin (PFX) mesilata i ciprofloksacin (CIP) hidroklorida u DMSO- $d_{6}$ otopini s ciljem da se istraži utjecaj supstituenata i tipa soli na NMR parametre bicikličkog 
M. Jadrijević-Mladar Takač: Effects of substituents on the NMR features of basic bicyclic ring systems of fluoroquinolone antibiotics and the relationships between NMR chemical shifts, molecular descriptors and drug-likeness parameters, Acta Pharm. 60 (2010) $237-254$.

fluorokinolonskog i fluoronaftiridonskog prstenastog sustava. Analizom jedno- i dvo-dimenzijskih, homo- i hetero-nuklearnih ${ }^{1} \mathrm{H}-\mathrm{i}{ }^{13} \mathrm{C}-\mathrm{NMR}$ spektara potvrđena je struktura ispitivanih fluorokinolonskih soli.

${ }^{1} \mathrm{H}$ - i ${ }^{13} \mathrm{C}-\mathrm{NMR}$ kemijski pomaci temeljnih prstenastih sustava korelirani su s izračunatim molekulskim opisivačima (relativnom molekulskom masom, $M_{\mathrm{r}}$, topologijskom polarnom površinom, TPSA, lipofilnošću, miLog $P$ i volumenom, $V$ ) te $\mathrm{s}$ parametrima sličnosti s lijekovima poznate biološke aktivnosti, tj. s ligandom $\mathrm{G}$ protein-spregnutog receptora (GPCR ligand), ligandom ionskih kanala (ICL), inhibitorom kinaze (KI) i ligandom nuklearnog receptora (NRL) koji su izračunati za monoprotonske katione ispitivanih fluorokinolonskih soli $\left(\mathrm{TVAH}^{+}, \mathrm{PFXH}^{+}\right.$and $\left.\mathrm{CIPH}^{+}\right)$.

${ }^{13} \mathrm{C}-\mathrm{NMR}$ kemijski pomaci C4, C5 i C11 atoma i ${ }^{1} \mathrm{H}-\mathrm{NMR}$ kemijski pomaci protona $\mathrm{u}$ $\mathrm{COOH}, \mathrm{H} 5 \mathrm{i} \mathrm{NH}_{n}{ }^{+}$ispitivanih fluorokinolonskih soli pokazali su se kao dobri parametri za istraživanje odnosa svojstvo-svojstvo i svojstvo-sličnost s lijekovima poznate biološke aktivnosti. Tako je otkriven kolinearan odnos između ${ }^{13} \mathrm{C}-\mathrm{NMR}$ kemijskih pomaka C4, C5 i C11 atoma i izračunatih parametara za sličnost s KI-ls i NRL-ls, kao i kolinearnost s TPSA, miLog $P, M_{\mathrm{r}}$ i $V$ (C4 $\delta$, ppm s TPSA, $R=0,9964 ; \mathrm{C} 4 \delta$, ppm s miLog $P, R=0,9487$; C4 $\delta$, ppm s $M_{\mathrm{r}}, R=0,9629 ; \mathrm{C} 4 \delta$, ppm s $V, R=0,8547 ; \mathrm{C} 4 \delta$, ppm s KI-ls, $R=0,9461$ i C4 $\delta$, ppm s NRL-1s, $R=0,9996$; C5 $\delta$, ppm s miLog $P, R=0,9994$; C5 $\delta$, ppm s KI-ls, $R=$ 0,9990 i C5 $\delta$, ppm s NRL-1s, $R=0,9510$; C11 $\delta$, ppm s TPSA, $R=-0,9958$; C11 $\delta$, ppm s KI-ls, $R=-0,9481$ i C11 $\delta$, ppm s NRL-ls, $R=-0,9994)$.

${ }^{1} \mathrm{H}-\mathrm{NMR}$ kemijski pomaci protona $\mathrm{COOH}, \mathrm{H} 5 \mathrm{i} \mathrm{NH}_{n}{ }^{+}$pokazali su kolinearnost odnosa s TPSA i miLogP, te s izračunatim parametrima za KI-ls, NRL-ls i GPCRl-ls $(\delta$, ppm $\mathrm{H}$ u COOH s TPSA, $R=-0,9421 ; \delta$, ppm H u COOH s NRL-ls, $R=-0,9216$; H5 $\delta$, ppm s miLog $P, R=0,9962 ; \delta$, ppm H5 s KI-ls, $R=0,9969 ; \delta$, ppm $\mathrm{NH}_{n}{ }^{+}$s TPSA, $R=$ $-0,9875 ; \delta, \mathrm{ppm} \mathrm{NH}_{n}{ }^{+}$s NRL-ls, $R=-0,9948 ; \delta$, ppm $\mathrm{NH}_{n}{ }^{+}$s GPCR ligandom, $\left.R=0,9873\right)$.

Rezultati istraživanja pokazali su razliku u eksperimentalnim i izračunatim parametrima za TVA mesilat u usporedbi s PFX mesilatom i CIP hidrokloridom, te je nađena značajna kolinearnost među ispitivanim parametrima ovih fluorokinolonskih antibiotika.

Ključne riječi: fluorokionolonski antibiotici, trovafloksacin, pefloksacin, ciprofloksacin, ${ }^{1} \mathrm{H}-\mathrm{NMR}$ spektroskopija, ${ }^{13} \mathrm{C}-\mathrm{NMR}$ spektroskopija, molekulski opisivači, parametri sličnosti s lijekovima, QSAR 